results with the Boys' camera), locomotives, Iubricants, metallography, silks (natural and artificial), sound (measurement, recording, reproduction, etc.), steam engines and turbines, tolevision, thermionics, vitamins, as well as such departments of work as magnetism, navigation, telegraphy and telephony, and so on. Finally, there is a comprehensive bibliography containing classified lists of books and other sources of information on subjects of scientific and technical importance.

We have already consulted the Encyclopædia many times and it has usually responded satisfactorily to the inquiry. There is, however, no entry under "Positron", and though the title "SaccharimetrySee Polarimetry" appears in its alphabetical place, there is no entry under "Polarimetry", and we miss the description of either a saccharimeter or a polarimeter.

The particular value of a work of this kind is no doubt on the side of applied science, though some attention is given to biological subjects. Even an Encyclopædia of 2,500 pages and more than 25,000 titles cannot provide much more than first-aid information upon any scientific or technical subject, but this service is afforded in the work now completed. It will be a long time before any British editors or publishers plan or produce a better descriptive guide to the position and importance of most points in the very extended field of precise knowledge and its application to industry.

\section{Things to Come}

By H. G. Wells. A Film Story based on the Material contained in his History of the Future "The Shape of Things to Come". Pp. 142. (London: The Cresset Press, 1935.) 3s. 6d. net.

Even more vividly than in the argument of "The Shape of Things to Come", Mr. H. G. Wells depicts the swift downfall of modern civilisation and the rise of a new and scientific order of society. His adaptation to the writing of a novel of something of the technique of a film story enables him to emphasise the more forcefully the inevitableness of some such order of society as an alternative to war. Equally without unduly stressing the horrors of warfare, his dramatic technique may perhaps stimulate many to realise the dangers of the present situation on whom the logical analysis of Sir Norman Angell, for example, would be lost. The scientific worker may well find as much interest in the technique with which Mr. Wells develops his argument as in the picture he gives of an imaginary scientific age.

Even more pertinent, however, is the question which Mr. Wells inevitably raises in the mind of all. Must mankind pass through such a period of disaster and collapse, or is there still time to regain control and so organise the resources and powers which science has put into man's hands that the surplus energies of the race spend themselves upon constructive and creative art and science?

The pictorial technique adopted by Mr. Wells will prove more than justified if it can stimulate a forward look and a willingness to try new methods before catastrophe ensues in quarters which have hitherto been noted for mankind's direst peril - a belated mind.

\section{Nouveau traité de psychologie}

Par Prof. Georges Dumas. Tome 4: Les fonctions générales d'organisation. Les lois générales de l'activité mentale. Avec la collaboration de Prof. Ch. Blondel, Prof. E. Claparède, Prof. H. Delacroix, Prof. P. Janet, Prof. H. Piéron, Prof. G. Poyer, Prof. R. Revault d'Allones. Pp. vi +528. (Paris: Félix Alcan, 1934.) n.p.

THE fourth volume of this collective treatise possesses all the qualities of scholarship, clearness and accuracy which have distinguished this standard work from the beginning of its publication. It deals mainly with the general functions of organisation and mental activity, such as attention, memory, habit, association of ideas, schematisation, symbolisation and the physiological aspects of mental activity. The chapter on schematisation (pp. 161-264) contains a number of controversial points, such as the distinctions and relations between schematisation on one hand and concept, judgment and reasoning on the other. Those who are interested in mathematics and science in general would have liked to find a discussion of the process of symbolisation in those fields of knowledge. But perhaps Prof. Dumas has left over these questions for the next volume, which is to deal with the higher functions of the mind. We might also mention the excellont chapter on the psychology of sleep by Prof. Claparède, with the - remark that this subject raises many more problems than can at present be answered. The practical value of this volume would have been greater if it had been provided with an index. T. G.

\section{Unsolved Problems of Science}

By A. W. Haslett. Pp. xi+317. (London: G. Bell and Sons, Ltd., 1935.) $7 s .6 d$. net.

A series of articles in the Morning Post, of which the author is scientific correspondent, formed the idea for this book. It "was to be popular yet accurate; stimulating to the layman yet not without value to the scientist; emphasising the unknown, yet providing, incidentally, a reliable picture of what was already known". The author, while not expecting to reach this ideal, has in many places closely approached it. The style is distinctly journalistic ; for example, Cockcroft and Walton are referred to as "the original large scale atom-splitters". A few of the statements are rather wild and might be a little misleading to the layman for whom the book is primarily intended; on p. 6, for example, we read, "Plasticene-was at one stage of very real importance in the exploration of the atom", surely a pointless statement since the same might be said of many other materials commonly employed in the apparatus. Then again, on p. 284, "The physicist has a long way to go yet before he will have satisfied his colleague the engineer that he knows what he is talking about," which is scarcely a happy way of expressing what the author evidently has in mind. Except for these occasional lapses, the book is enjoy. able and worth reading, covering as it does the whole field of science in a representative way. H. R. L. 